\title{
Annelise Schulte Nordholt, Le moi créateur dans «A la recherche du temps perdu»
}

\section{Emanuele Kanceff}

\section{Q OpenEdition}

1 Journals

\section{Edizione digitale}

URL: http://journals.openedition.org/studifrancesi/35116

DOI: 10.4000/studifrancesi.35116

ISSN: 2421-5856

\section{Editore}

Rosenberg \& Sellier

\section{Edizione cartacea}

Data di pubblicazione: 1 novembre 2005

Paginazione: 447

ISSN: 0039-2944

\section{Notizia bibliografica digitale}

Emanuele Kanceff, «Annelise Schulte Nordholt, Le moi créateur dans «A la recherche du temps perdu»», Studi Francesi [Online], 146 (XLIX | II) | 2005, online dal 30 novembre 2015, consultato il 18 avril 2021. URL: http://journals.openedition.org/studifrancesi/35116 ; DOI: https://doi.org/10.4000/studifrancesi. 35116

Questo documento è stato generato automaticamente il 18 avril 2021.

\section{(c) (1)}

Studi Francesi è distribuita con Licenza Creative Commons Attribuzione - Non commerciale - Non opere derivate 4.0 Internazionale. 


\title{
Annelise Schulte Nordholt, Le moi créateur dans «A la recherche du temps perdu»
}

\author{
Emanuele Kanceff
}

\section{NOTIZIA}

ANNELISE SCHULTE NORDHOLT, Le moi créateur dans «A la recherche du temps perdu», Paris, L'Harmattan. («Critiques Littéraires» dirigée par Maguy Albet et Paule Plouvier), 2002, $263 \mathrm{p}$.

1 L'autrice parte dalla definizione che Gérard Genette ha dato della Recherche. «Marcel devient écrivain». Ma come si compie questa lunga metamorfosi di Marcel. Come si trasforma questo io vivente in io scrivente?

Questione certamente primaria quella di riconoscere la nascita dell'io creatore. Questo studio intende proporre una risposta nuova a tali interrogativi. Non vi sarebbe, all'origine dell'atto creativo, alcuna memoria involontaria che riconduce alla vita gli esseri e le cose e li salva dall'oblio; piuttosto, l'esperienza dolorosa della frammentazione e della perdita dell'io, che si esprime in due direzioni, i risvegli e il senso della morte dell'essere amato.

3 La riflessione dell'autore evolve così dallo studio dell'io misterioso, del protagonista $\mathrm{e}$ dell'uomo Marcel, seguito nel suo formarsi e nelle evoluzioni che leinfluenze gli impongono, da Tadié a Schopenhauer a Bataille e Blanchot, verso lo studio del «dormeur éveillé e della sua funzione di soggetto intermediario, fino al «vedersi dormiente» nel dono della memoria. Due capitoli importanti sono poi dedicati al «drame du coucher» e all'io «en deuil», per venire poi ad esaminare «les intermittences $\mathrm{du}$ coeur», che vengono valutate nella loro funzione in rapporto alla creazione letteraria e introducono al capitolo finale, dedicato al «moi créateur». Così, difronte al 
crimine inconfessabile delle «mères profanées», si apre il cammino dellespiazione e della speranza di redenzione attraverso la scrittura. 